\title{
How can ECAs Help Solve Funding Challenges for Capital Intensive Projects in Emerging Market Economies?
}

\begin{abstract}
This article discusses challenges faced by companies in emerging markets when funding capital intensive projects and purchasing equipment from companies in advanced economies. The article analyses the funding and risk mitigation instruments of Export Credit Agencies to show how they work and how they can provide a solution both for the buyers of equipment in emerging markets and the sellers in advanced economies.
\end{abstract}

Keywords: Cross border trade, emerging markets, financial crisis, export credit agencies (ECAs), commercial and non-commercial risks, risk mitigation instruments, project financing.

Šiame straipsnyje aptariami sunkumai, su kuriais susiduria besivystančių šalių ịmonės, finansuodamos kapitalui imlius projektus ir ịsigydamos ịrangą iš išsivysčiusių šalių įmonių. Straipsnyje analizuojamos eksporto kredito agentūrų (EKA) finansavimo ir rizikos mažinimo priemonès, parodant kaip jos veikia ir kaip padeda rasti alternatyvius sprendimus besivystančių šalių ịrangos pirkejjams ir išsivysčiusių šalių ịrangos pardavèjams.

Raktiniai žodžiai: tarptautinè prekyba, besivystančios rinkos, finansų krizė, eksporto kredito agentūros (EKA), verslo ir ne verslo rizikos, rizikos mažinimo priemonès, projektų finansavimas.

JEL Classifications: F14/F21/G01/G24/G32.

\section{Introduction}

Many emerging countries in the world remain middle income. All those countries are striving to achieve high income status in the future. Among the key challenges that middle income countries face is the modernization of their export sector, which can help increase the value added of their production. To modernize their export industries, companies in emerging middle income countries often need to engage in trade with companies in advanced high income countries e. g. when purchase advanced processing solutions. On one hand, advanced high income economies seek to boost the export of their home products, including capital goods, to emerging markets where rewards can be high. While trade with emerging markets can offer substantial profits, they also often present high levels of risks. On the other hand, companies in emerging market countries are often faced with challenges

Trung Quang DINH - M.Sc. in International Business, School of Business and Science, University of Akureyri, Iceland; e-mail: quangtrung38@gmail.com.

Hilmar Pór HILMARSSON - Prof. dr., School of Business and Science, University of Akureyri, Iceland. Address: Borgir v/Nordurslod 600, Akureyri, Iceland; phone: 00354849 8380. Visiting Professor, Stockholm School of Economics in Riga, Latvia; e-mail: hilmar@unak.is. 
in modernizing their processing lines due to difficulties in accessing long term funding. This article discusses how export credit agencies (ECAs) can provide a solution for companies in both emerging and advanced economies.

The current economic and financial crisis resulted in a sharp fall in international trade in the second half of 2008 and early 2009. According to a recent IMF working paper ECAs played an important role in cushioning this downturn. The same IMF paper argued that ECAs "may also have played an important signaling role by reassuring the private sector that official institutions stand ready to back up at difficult times." (Asmundson et al., 2011). In addition to facilitating cross border trade during times of crisis ECAs can also help companies in emerging countries access long term funding at lower interest rates than they could access locally. This can help companies modernize their processing lines, especially processing companies engaged in exporting that use capital intensive equipment. This can also be important for emerging economies in transition that need to increase the value added of their industries to upgrade from low or middle income to high income status. The objective of this article is to discuss how export credit agencies can facilitate cross border trade between companies in advanced economies and emerging market economies. It will analyze and discuss the use of ECAs' instruments to show how those instruments can help companies from advanced economies export more capital goods and manage risks in emerging markets. The article will also demonstrate how companies in emerging economies can obtain long term funding at lower interest rates to modernize their processing lines and thus increase the value added in their production. The aim of the article is to demonstrate to business managers how the instruments of ECAs can be mutually beneficial for trading partners in emerging markets and advanced economies.

Discussion in the article will be structured as follows: First, introduction. Second, literature and background review for ECAs, as well as definitions of commercial and non-commercial (political) risks. This section also introduces the role of ECAs during times of crisis and reviews some economic justification for ECAs and theoretical considerations. Third, methodology. The methodology used in this article is the case study method. Compared with other research methods, a case study enables the researcher to examine the issues at hand in greater depth. Among the sources of evidence used for the analysis in this article are interviews with four of the largest fish processors in Vietnam and ECAs in Denmark, the Netherlands, Singapore and Sweden. Documentation/secondary data, including reports and scholarly literature are also used. Direct observation also plays a role in this article as the authors draw on field visits to four of the largest fish processors in Vietnam in November 2011. Other cases from Vietnam, Jordan and Ukraine consisting of secondary information from the Danish ECA, EKN, are used to illustrate how ECA instruments have been applied in real world situations. Fourth, risk mitigation instruments offered by ECAs are discussed, Fifth, cases that demonstrate application of ECA risk mitigation instruments, including findings from primary research conducted by the authors in co-operation with a large Icelandic company, Marel, in Vietnam. Marel is engaged in manufacturing food processing equipment and has production facilities in a number of countries in Europe, America 
and Asia. This example demonstrates how Vietnamese companies could benefit from the services of ECAs when upgrading their processing lines and increase their value added. And finally, conclusions.

\section{Literature and Background Review}

\section{ECAs, Commercial and Non- commercial Risks - Some Definitions}

What are ECAs and how do they function? On the website of the OECD one can find the following information "Governments provide official export credits through Export Credit Agencies (ECAs) in support of national exporters competing for overseas sales. ECAs provide credits to foreign buyers either directly or via private financial institutions benefiting from their insurance or guarantee cover. ECAs can be government institutions or private companies operating on behalf of the government" (OECD n.d.).

Thus ECAs facilitate cross border trade by providing insurance or guarantees against commercial and non-commercial/ political risks. But what are those risks? MIGA defines political risk broadly as "the probability of disruption of the operations of MNEs by political forces or events, whether they occur in host countries, home country, or result from changes in the international environment. In host countries, political risk is largely determined by uncertainty over the actions of governments and political institutions, but also of minority groups, such as separatist movements. In home countries, political risk may stem from political actions directly aimed at investment destinations, such as sanctions, or from policies that restrict outward investment" (MIGA, 2009). The Oxford Handbook of international Business defines political risk as "the probability of disruption to MNE's operations from political forces or events and their correlates. It involves governmental or societal actions, originating either within or outside the host country, and negatively affecting foreign companies' operations and investments. Political risk reflects the degree of uncertainty associated with the pattern of decisions made by the political institutions such as governmental and legislative agencies"1 (Luo, 2009).

Commercial risk is defined by the OECD (in the context of export credits) as "the risk of nonpayment by a non-sovereign or private sector buyer or borrower in his or her domestic currency arising from default, insolvency, and/or a failure to take up goods that have been shipped according to the supply contract" (OECD, 2003).

For the purpose of this article we will be concerned with commercial and noncommercial risks faced by exporters who wish to engage in cross border trade to emerging market economies. Those economies are often undergoing a political and economic transition which makes private sector engagement more challenging than when exporting to developed economies. Companies entering emerging markets can expect to face higher market barriers and more political uncertainties than those entering developed high income countries.

\section{Why are ECAs Important During Times of Global Crisis?}

Among the key characteristics of the East Asian growth model is the emphasis on export. Indeed, its growth in recent years 
has been export led. The current economic and financial crisis has severely affected trade flows. A recent IMF Working Paper referred to above shows that exports by advanced, emerging, and developing nations were all growing strongly through mid-2008 but then dropped sharply in the second half of 2008 and 2009 (Asmundson et al., 2011). According to the IMF working paper, prompt action by the G-20 and ECAs likely helped keep trade flowing during the worst of the disruptions (Asmundson et al., 2011). A recent column published by two World Bank staff members, entitled "Export credit agencies to the rescue of trade finance", argues that export credit agencies played a key role in stabilizing the trade finance market. They also refer to surveys that have detected an increased need for more guarantees and insurance to facilitate the release of trade finance funds (Chauffour and Saborowski, 2010). Furthermore, according to Steve Tvardek at the OECD, when discussing trade flows in the aftermath of the economic and financial crisis that started in the fall of 2008, "ECAs not only became more important than ever as a source of trade finance, they actually became one of the principal policy tools governments used to cushion the real economy from the chaos in the markets" (Tverdek, 2011). Demand for the services of many ECAs increased during the crisis. For example according to EKN, the Swedish Export Credit Agency, the volume of guarantees issued increased from more than SEK 20 billion in 2007 to more than SEK 115 billion in 2010 (EKN, 2010). This evidence unequivocally illustrates that risk mitigation instruments are in high demand in a country like Sweden, especially during times of crisis.

\section{ECAs - Theoretical Considerations}

What are some of the economic justifications for export credit agencies? According to Raoul Ascari ${ }^{2}$ the rationale for establishing an ECA has never been spelled out in a definitive way. Furthermore he states that "economic literature on this line of research has almost disappeared over the last two decades" (Ascari, 2007). Ascari, however, refers to the World Bank Research Observer from 1989 that lists some rationales behind export credits. These are: domestic distortions, capital market failures ${ }^{3}$; risk uncertainty and incomplete insurance markets; moral haz$\operatorname{ard}^{4}$, and adverse selection ${ }^{5}$. As Ascari points out, moral hazard and adverse selection may raise premiums above the threshold at which exporters are willing to buy insurance (Ascari, 2007). Other rationales for export credit and insurance are: industrial policies; export externalities; employment and balance of payments and matching other countries programs (for detail, see Fitzgerald and Monson, 1989; Ascari, 2007).

According to a report published by the WTO in 1999, aggravated asymmetric information ${ }^{6}$ in cross border trade, and the inability or unwillingness of private commercial banks to take on economic/commercial risks and politi$\mathrm{cal} /$ non-commercial risks is often seen as an economic justification in trade financing (Finger and Schuknecht, 1999). This is especially true for large and longterm trade contracts to countries with less developed financial systems. Clearly asymmetric information can be significantly larger in international trade, as compared with domestic trade. This is because information about foreign companies (e. g. importers) is often more 
limited or less familiar to the supplier or exporter and their bank than in the case of domestic clients. This problem relates to commercial risks. Another problem associated with distant markets has to do with policy changes which make transfer of foreign exchange difficult or impossible thereby preventing the importer/ purchaser from making a payment to the exporter/supplier. This problem relates to non-commercial risks.

ECAs from high income developed countries can help in this process if they guarantee exports to emerging markets and by doing so reduce the need for domestic financing. ECAs can provide cover for both commercial and non-commercial risks. In fact, most developed countries have ECAs that help promote exports. As Finger and Schuknecht point out ECAs provide trade related financing through three main instruments: (i) credits for trade transactions which would be difficult or more costly to finance via commercial lending, (ii) guarantees for repayment of credits which help exporters obtain more favorable lending terms from their local or international banks, (iii) insurance for exporters against commercial and non-commercial/political risk (Finger and Schuknecht, 1999).

\section{Methodology}

The methodology used in this article is the case study method. Compared with other research methods, a case study enables the researcher to examine the issues at hand in greater depth. According to R. K. Yin (2009), six sources of evidence are most commonly used in doing case studies. These are: documentation, archival records, interviews, direct observations, participant-observation, and physical artifacts. Each of these sources has advantages and disadvantages and according to Yin one should "note that no single source has a complete advantage over all the others. In fact, the various sources are highly complementary, and a good case study will therefore want to use as many sources as possible" (Yin, 2009). Among the sources of evidence used for the analysis in this article are interviews with four of the largest fish processors in Vietnam and ECAs in Denmark, the Netherlands, Singapore and Sweden. Documentation/secondary data, including reports and scholarly literature are also used. Direct observation also plays a role in this article as the authors draw on field visits to four of the largest fish processors in Vietnam in November 2011. Other cases from Vietnam, Jordan and Ukraine consisting of secondary information from the Danish ECA, EKN, are used to illustrate how ECA instruments have been applied in real world situations. Case studies do not present results that can be evaluated on the basis of statistical significance and one should be careful in generalizing findings of one case study on other cases or situations. However, some lessons from the study on Vietnam may have wider relevance than for Vietnam only. This is especially true for emerging market countries with large processing industries, requiring capital intensive processing lines to increase the value added in their processing. This is also true for companies in emerging markets that have limited access to long term funds and that often face high and fluctuating real interest rates that complicate investment decisions and that can result in sub optimal processing solutions. 


\section{ECAs and Risk Mitigation Instruments}

When private companies engage in cross border trade in emerging markets, the risks they face is a key concern. Managing those risks will be one of the primary objectives of the company. Not only do small and medium sized companies need to carefully evaluate and assess the risks they are faced with, but also large corporations with stronger financial capabilities need to protect their business from risks. In order to meet this existing demand the political and commercial risk insurance industry has been formed. The leading association in this industry is the Berne Union (founded 1934) with 73 members including mainly ECAs, multilaterals, and private insurers (MIGA, 2010). ECAs are either public-sector institutions in their respective countries, established to provide support for the exports of that country, or private-sector companies that act as a channel for government support for exports from the country concerned (Yescombe, 2002).

In general, ECAs will charge a premium to companies that use their products. According to MIGA the "OECD country ratings are designed to set guidelines to price the default risk on export credit and to set minimum premium rates charged by participating ECAs" (MIGA, 2010). The ratings known as the Knaepen Package which came into effect in 1999 is a system for assessing country credit risk and classifying countries into eight risk categories, from 0 to 7 (OECD, n.d). Basically, ECAs will assess political risk and commercial risk when they issue guarantees to exporters or foreign buyers. ECAs use country ratings by OECD as a platform to assess political risk or country risk while commercial risk is assessed based on each individual company's information such as operational and background information, financial and audited annual reports, project feasibility studies, and the like. Companies that are eligible to use products or services provided by an ECA must have operations relevant to the national interest of the country where the ECA is located. In other words, companies must contribute to the national economic development of that country in a direct or indirect way. For instance, a company must have production facilities located in the home country of the ECA. An ECA may also support a home company that has a production facility in a host country.

Various products or risk mitigation instruments are offered by ECAs and these products can be the same or very similar from one ECA to another. ECA products include, for example: Bond Guarantee, Investment Guarantee, Project Financing Guarantee, Financing Guarantee, Project Delivery Guarantee, Working Capital Guarantee, or Reinsurance.

The products that this article focuses on and analyses are: (i) Buyer Credit Guarantee, (ii) Supplier Credit Guarantees and (iii) Export Loans. The authors of this article chose these three products based on their research of a large European company, Marel, in connection with its business expansion in Vietnam. These products seem suitable for risk mitigation when companies export goods or services to their buyers in emerging markets. However, companies need to find what product suits them best on a case by case basis.

A Buyer Credit Guarantee is basically a guarantee issued by an ECA to a bank that lends money to a foreign importer to pay for an order of goods or services from an exporter in the country where the 
ECA is located (see Fig. 1). In emerging market countries, both local and international banks are cautious when deciding to lend capital to companies. Field research ${ }^{7}$ among the largest fisheries processors (ranked by VASEP ${ }^{8}$ ) in Vietnam conducted by the authors in November 2011 found that when companies applied for medium or long-term loans (up to 5 years) to invest in processing equipment they usually only got $50 \%$ to $55 \%$ of the amount requested. If a company has good working experience and good relations with a local bank and the feasibility study of their project is highly assessed, the amount of loan could be increased to $70 \%$ of the total loan requested. Companies had to use their own funds for the rest of the investment. Some processors said that they could hardly obtain any medium or long term loan if the size of the loan is up to few million US dollars. This has been one of the companies' main constraints and prevents companies from investing in comprehensive and modern processing lines. Often they end up buying piecemeal solutions that are unlikely to result in optimal value added in that industry.

The exporter sells goods/services to $a$ foreign buyer and proposes that the buyer

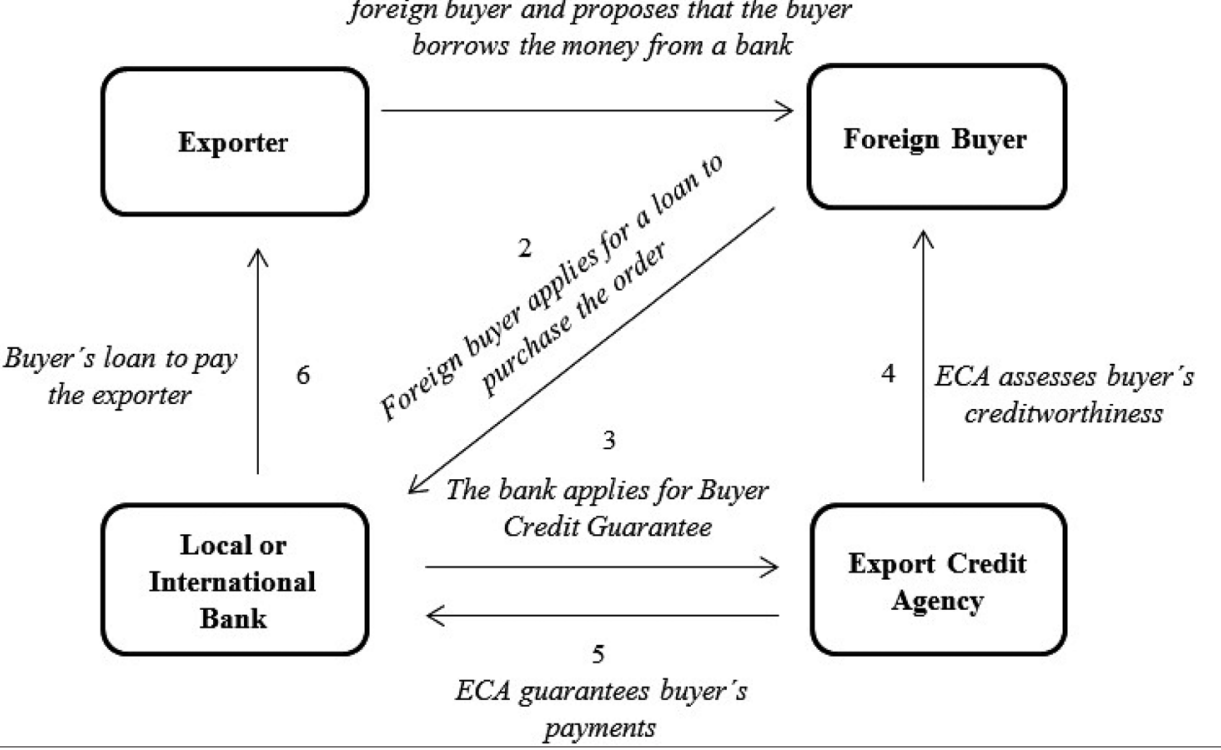

Fig. 1. Model of Buyer Credit Guarantee

Source: Constructed by the authors. 
A Buyer Credit Guarantee can help foreign buyers in emerging markets to obtain larger loans from international banks with a longer lending term and at more favourable interest rates. This can also be done through a local bank but would normally take longer as the ECA is more likely to know the international banks. The bank will then be covered from buyer default in repayment due to either commercial or non-commercial risks.

A Supplier Credit Guarantee is a guarantee issued by an ECA to the supplier or the exporter and the exporter can then grant the foreign buyer extended credit on amounts payable for the order. The supplier or the exporter will be protected against the risk of non payment by the buyer or the importer due to political or commercial risks. The exporter can take advantage of a supplier credit guarantee to lend to foreign buyers in an emerging market where an extended credit period may be the key incentive for buyers to select the most competitive supplier over the others. A Supplier Credit
Guarantee helps the buyer or importer pay for the order over a longer period (see Fig. 2). This can be highly advantageous for a buyer who may have limited cash flow and has difficulty in accessing funds. During research conducted by the authors of this article among the 20 largest Vietnamese fisheries processors in August 2011, a questionnaire was distributed. All of those who answered indicated that they have to pay the supplier within 3 to 6 months after the equipment has been fully installed and checked. This short term repayment period for the equipment from the supplier is one of their main constraints especially for companies that lack working capital and have difficulty in obtaining loans. Field research by the authors in November 2011 found that these companies had not been offered an extended credit period by any supplier. They have to apply for loans from local banks with high interest rates. Most loans are short term loans (less than 12 months) and the amount allocated is far lower than the amount requested. This constraint

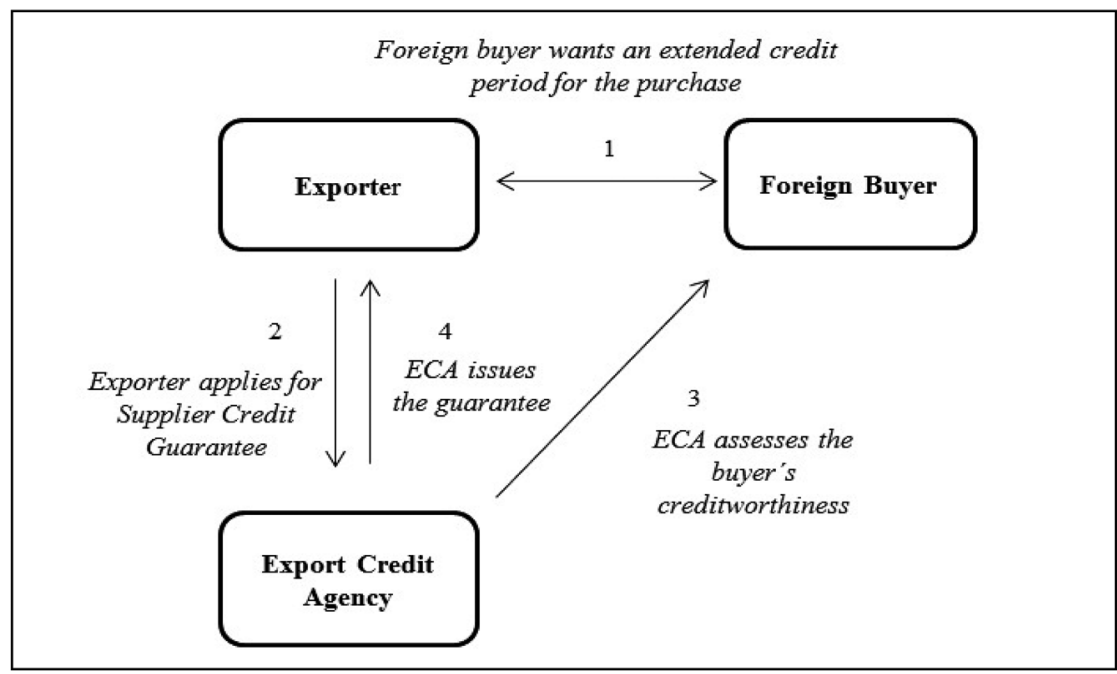

Fig. 2. Model of Supplier Credit Guarantee

Source: Constructed by the authors. 
appears to be one of the reasons why Vietnamese fisheries processors could not purchase sophisticated processing equipment from European manufacturers on a large scale. Comprehensive processing lines are not affordable for these processors.

They only purchased a small part of the equipment needed from these manufacturers and the rest of processing lines were locally made or imported from more affordable Asian manufacturers such as China. This suggests that if buyers from an emerging market like Vietnam were offered an extended credit period, it might affect their investment decision. In turn, this means that they would perhaps invest in more sophisticated processing equipment on a larger scale. Some of the processors in Vietnam indicated that if they were granted a longer repayment period from the supplier and at reasonable cost they would consider investing in and modernizing their processing lines more comprehensively. See Fig. 2 for a description of how a Supplier Credit Guarantee works.
An export loan is a lending scheme to help the exporter's foreign buyer when the buyer is unable to secure credit facilities from banks to purchase products and services from the exporter (see Fig. 3). In the case of EKF (the Danish Export Credit Agency), they would facilitate an export loan through a bank, and the loan is based on the bank's lending terms. It depends on each individual ECA whether or not they offer the export loan product and how long the lending term will be. But this product is very important during a financial crisis when banks are unable to provide loans to companies. EKF offers export loans as a result of the crisis and an application for an export loan from EKF can be made until the end of 2015.

However, the costs associated with and the premium for this Export Loan scheme are not necessarily cheaper than other traditional lending schemes because the export loan is granted jointly by a bank (usually the exporter's bank) and an ECA to the foreign buyer on a commercial basis

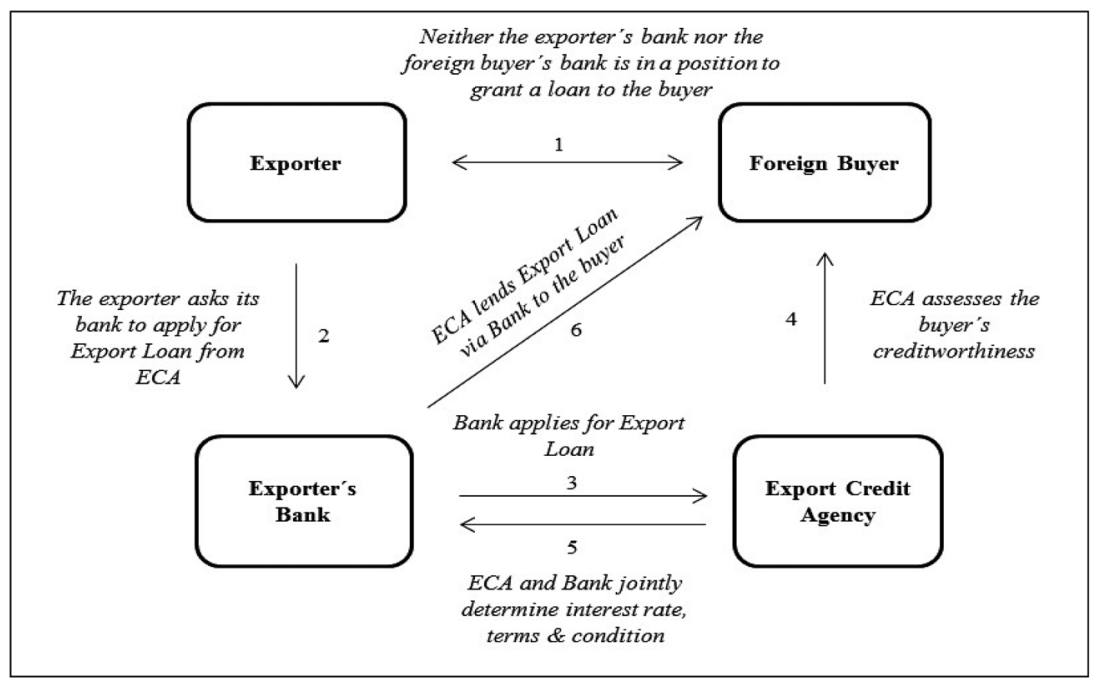

Fig. 3. Model of Export Loan

Source: Constructed by the authors. 
and market conditions. An export loan can be even more expensive but it also can be critically important in international trade especially during a time of financial crisis when many banks are unable to provide funds to companies. The next section will illustrate how this product is applied by reference to a case in Jordan.

\section{Application of ECA Risk Mitigation Instruments - Selected Cases}

The opening up of emerging market economies for cross border trade provides companies with many new opportunities but at the same time it involves international business risks. This section discusses some success stories of companies that used products of the Danish Export Credit Agency (EKF) when engaging in cross border trade. These cases are quoted directly from cases published on the EKF website.

\section{Olam International Limited and use of Buyer Credit Guarantee from Danish ECA (EKF) - for Manufacturing Facility in Vietnam (2009)}

Olam is a leading global supply chain manager and processor of agricultural products and food ingredients. With direct sourcing and processing in most major producing countries for various products, with its headquarters in Singapore, Olam has built a global leadership position in many businesses, including cocoa, coffee, cashew, sesame, rice, cotton, and wood products. Olam operates an integrated supply chain for 20 products in 65 countries, delivering these products to over 11,000 customers worldwide (Olam, 2011).
The Challenge: In 2009, Olam was looking to invest in equipment for its new coffee manufacturing facility in Vietnam. Olam chose a Danish company, namely GEA Process Engineering A/S, as the supplier. Unfortunately, the global economic and financial crisis made it difficult for Olam to secure the financing it needed to buy the equipment. At the same time, Olam's bank was reluctant to secure long term financing. "Owing to the lack of liquidity in the financial market in February 2009 it would in all probability have been impossible to secure financing with a repayment term beyond 2-3 years for Olam," says Antero Ranta from Olam's bank, ANZ Structured Asset and Export Finance, in Singapore.

The Process: Thanks to long standing working relations between GEA and EKF, GEA proposed that EKF should be involved in the process of procuring financing for Olam's project in Vietnam. "I was convinced that EKF would be able to assist in putting the financing in place. For our part, it was all plain sailing, as, right from the start, our customer and ANZ were keen to take over and deal with EKF directly," says Jesper Duckert, Project Finance Manager, GEA Process Engineering A/S. In order to implement the financing negotiations, EKF decided to send its representatives to Vietnam and had a meeting with representatives from Olam and ANZ Structured Asset. After the visit to Vietnam, EKF had a better basis for assessing the actual credit risk entailed by the project.

The Solution: After the meeting and negotiation EKF came up with a detailed assessment of the project and was able to offer a buyer credit guarantee. This guarantee meant that EKF assumed a share of the risk of extending a loan to Olam, so that ANZ could secure financing for Olam 
as they needed. "With an export credit guarantee from EKF we were able to offer Olam a loan with a repayment term of 8,5 years," says Antero Ranta from ANZ Structured Asset and Export Finance in Singapore. "In spite of the financial crisis we were able to secure long-term financing for our activities on a growth market", says Arun Sharma, Senior Vice President, Coffee Division, Olam (EKF, 2009a).

\section{Jordanian Company Modern Cement \& Mining Company, and use of Export Loan and Buyer Credit Guarantee from Danish ECA (EKF) (period of credit: 2010 to 2017)}

The Challenge: In July 2008 the Jordanian company Modern Cement \& Mining Company chose a Danish company, namely FLSmidth, as an equipment supplier for its new cement plant in the south of Amman. The first deliveries were already paid for by the Jordanian company but the main part of the order was to be financed by a local bank. However, due to the global economic and financial crisis, the bank turned down applications for new loans. This threatened the progress of construction and the order of FLSmidth. FLSmidth decided to contact EKF in the spring of 2009 because FLSmidth had previously been assisted by EKF with guarantees for financing solutions.

The Process: EKF had meetings with a number of international and local banks which expressed their interest in taking on the risks of the project provided that EKF would guarantee most of the loans. Furthermore, through the export lending scheme EKF was able to offer a loan to the buyer of FLSmidth services. Then EKF quickly endorsed the project. "EKF's endorsement was conditional to the approval of the risks and terms in the transaction, its environmental impact and the extent of the Danish economic interest in the transaction - aspects which all needed further examination and subsequent negotiation with the parties involved" (EKF, 2010).

The Solution: Finally the solution came into place in May 2010. "Half of the FLSmidth contract was financed with equity from the owners of the cement plant while the other half was financed with loans. More than half of the debt financing came from the Danish export lending scheme administered by EKF, while the remainder was provided by a group of local banks" (EKF, 2010). HSBC London arranged the EKF financing. HSBC London is also acting as agent bank on behalf of EKF. Thanks to the EKF loan and guarantee, construction of the cement plant in Jordan could continue as planned. And the plant was expected to be ready for production startup at the beginning of 2012 (EKF, 2010).

\section{Ukrainian Grain and Seed Exporter Nibulon Company uses EKF's Buyer Credit Guarantee to Borrow Money from a European Bank at a far Lower Interest Rate than in} Ukraine

The Challenge: In 2009, a Danish company, Cimbria Unigrain, received the first of two large orders worth EUR 20 million from Nibulon, Ukraine's largest grain and seed exporter and a highgrowth company. The order consisted of eight silo facilities for storing, drying and loading grain and seed. Nibulon needed this equipment to extend and standardize its storage and transportation facilities 
by the rivers of Ukraine and the Black Sea. However, the Ukrainian buyer's constraint was that they had to borrow at a high interest rate in Ukraine to pay Cimbria Unigrain. And this might create uncertainty regarding the order from the Danish manufacturer.

The Process: Cimbria contacted EKF and EKF agreed to assess the viability of the export order and work on the financing options via a guarantee from EKF. "Even allowing for the premium payable to EKF, Nibulon is making a big saving", said Sales Director Henning Roslev Bukh. He added that Nibulon regarded Cimbria Unigrain and EKF as important and regular business partners.

The Solution: Finally EKF offered a buyer credit guarantee to Nibulon. This meant that Nibulon was able to secure a loan from a western European Bank at a far lower interest rate than in Ukraine. "Nibulon is very pleased that it was possible to arrange a Danish guarantee for this order. We might well have got the order anyway, as Nibulon has ordered from us for many years and is very satisfied with our products. Nibulon could perhaps have financed the purchase with equity, but it is often cheaper to borrow the money than to use equity, and equity is greatly needed in a growth-oriented company such as Nibulon”, said Henning Roslev Bukh. Moreover in 2010 Nibulon placed another order for eight silo facilities - and once again EKF provided a guarantee for the buyer's payments. Thanks to this order Cimbria Unigrain hired 30 employees in 2010 (EKF, 2009b).

\section{Marel's Expansion in Vietnam}

Marel is one of the leading manufacturers internationally in food processing equipment and solutions. Marel is headquartered in Iceland ${ }^{9}$ and has production facilities for processing lines for fish, poultry, and meat in several European countries, in America, and in Asia. Marel is ambitious to expand its business in emerging markets where the food processing industry is becoming more important, as for example in China, Thailand and Vietnam. However, the purchasing volume of buyers from these markets remains low especially in Vietnam. Research conducted by the authors in cooperation with Marel, as mentioned above, among the largest pangasius processors in Vietnam, found that Vietnamese buyers bought some limited processing equipment rather than investing in comprehensive processing lines. During in-depth interviews with four of the largest Vietnamese processors, the authors were told that most of the equipment made by European manufacturers is very sophisticated and advanced. However, this equipment is too expensive for Vietnamese processors to purchase on a large scale. Instead, they had to select some equipment which is the most important for them. The remaining equipment they bought from more affordable manufacturers in China, Korea or Japan while some other equipment is locally made. When asked, these processors said they were aware of the fact that having advanced equipment in their processing lines would enable them to export more of their products to high income markets such as the USA, Europe and Japan. The critical issue was lack of funding, which prevented them from investing intensively. The issues here included a low amount of loan allocation from local banks, limited availability and accessibility to long term loans especially in foreign currency such as USD, high interest rates, short re- 
payment periods to equipment suppliers, and so on.

At the same time, the authors visited and interviewed some ECAs in Europe: EKF (Denmark), EKN (Sweden), Atradius (the Netherlands), and ECICS in Asia (Singapore). In response to the question what products offered by ECAs they thought would be most suitable for Marel and its buyers in Vietnam given the constraints mentioned above, these ECAs thought that two products should be suitable. These were the Buyer Credit Guarantee and the Supplier Credit Guarantee (described above). The recommended ECA products could help Marel achieve its goal: to expand its business in Vietnam. However, the ECAs also said that in order to be supported by ECA instruments, the Vietnamese buyers needed to fulfil requirements in terms of being able to provide sufficient and transparent information about their companies, especially financial information, including audited annual reports. The readiness and good "homework" of Vietnamese buyers will help the process of ECAs in assessing their creditworthiness and deciding on their request more quickly. Most of the Vietnamese fisheries processors are now working with local banks, both state owned and private. However, ECAs indicated that if foreign buyers work with international banks it will normally make the process faster because ECAs have more working experience with large international banks than local banks in a specific country.

\section{Conclusions}

This article discusses the challenges faced by private companies when funding capital intensive projects in emerging markets. The challenges here are faced by both companies (exporters) from advanced high income economies and companies (importers) in emerging middle income economies. The challenges faced by exporters are associated with risks in cross border trade with emerging markets while the challenges faced by importers are often related to the difficulties in accessing long term funding at affordable costs to modernize their projects or processing lines. The article also discussed the role of ECAs in facilitating cross border trade to emerging markets especially during times of crisis as well as the economic rationale for the existence of such agencies. ECAs played a critical role in cushioning the downturn in cross border trade during the economic and financial crisis that started in the fall of 2008.

Emerging economies that are moving towards more open trade provide companies in advanced economies with new trade opportunities. However, at the same time this involves international business risks. When companies engage in cross border trade they are likely to face higher risks than in domestic markets. These risks can be political and commercial risks. Moreover, the level of risk is also different in different markets. In order to cover existing demand and to promote the export of home products, ECAs worldwide provide various risk mitigation instruments for cross border trade. The cases described in this article show that real possibilities are available for companies to cover risks and thus enhance their business development especially when they tap into emerging markets that are in transition.

ECAs can facilitate cross border trade and can also help companies in emerging countries access long term funding at lower interest rates than they could access locally and thus make funding for capital intensive projects more feasible. This can 
be done both because an ECA guarantee reduces the risk for the lending bank and because borrowing in foreign currencies can lower interest rates. Borrowing in foreign currencies can be especially feasible for companies that receive income in the same foreign currency. Access to longer term loans at lower cost can help companies modernize their processing lines, especially those engaged in capital intensive activities, and enable economies in transition increase the value added of their industries.

To use the services of ECAs, companies need to enable ECAs to assess their creditworthiness. This is especially true for foreign buyers. Therefore, in response to this issue, foreign buyers need to provide full and transparent financial information to help the process move faster, including audited annual reports. The availability of audited financial statements according to international standards helps reduce the information asymmetry that exists between the ECA, the foreign exporting company and foreign bank on one hand, and the local company and the local bank on the other hand.

ECAs in high income countries often prefer working with international banks that they know and already have a business relationship with. Thus it could be advantageous for buyers in emerging markets to seek loans from international banks or international financial institutions such as the Asian Development Bank and the private sector of the World Bank, the International Finance Corporation.

Although this article mainly focuses on Vietnam, some lessons from the study may have wider relevance than for Vietnam only. This is especially true for emerging market countries with large processing industries, requiring capital intensive processing lines to increase the value added in their processing, and to boost export revenues. This is also true for companies in emerging markets that have limited access to long term funds and often face high and fluctuating real interest rates that complicate investment decisions and result in sub optimal processing solutions.

The risk mitigation instruments offered by ECAs show that the risks associated with political and commercial risks in emerging markets can be managed. Moreover, the cases discussed in this article are tangible evidence of recent success during a global economic and financial crisis. Those transactions would hardly have taken place unless the parties involved considered them beneficial. Nevertheless, more research needs to be done to access the costs of using the services of ECAs, on the one hand, and the benefits of longer term loans, possible with lower interest rates, on the other hand. This can, however, be difficult as ECAs, banks and companies engaged in cross border trade are often reluctant to share data on those transactions. 
Notes

1 Different conceptualization of political risk can lead to different data sources, analytical tools, and interpretation of results (Luo, 2009).

2 At the time of writing his paper (2007) Raoul Ascari was the CFO of SACE. Currently he is the Chief Operating Officer of SAGE. In an email to the authors dated February 22, 2012 R. Ascari confirmed that according to his knowledge this gap in the literature still exists.

3 Incomplete information on export risk can, for example, cause lenders to charge higher rates or to demand more collateral.

${ }^{4}$ Moral hazard is a problem created by asymmetric information after the transaction occurs. This occurs when the borrower engages in activities that are undesirable for the lender in the sense that they make it less likely that the borrower can pay back the loan. In the case of ECAs moral hazard would exist if an insured exporter has an incentive to change its behaviour once it has the insurance. The exporter would sell to a riskier importer and transfer higher risk than he would wish to bear in the absence of insurance.

${ }^{5}$ Adverse selection is a problem created by asymmetric information before the transaction takes place. This occurs, for example, when a borrower who is least likely to produce a desirable outcome most actively seeks a loan and thus is most likely to get the loan. Exporters would have an incentive to insure only high risk sales but not those that are considered low risk.

6 This implies that one party does not have enough information about the other party to make decisions. For example, a borrower who takes a loan often has better information about the potential returns on an investment project than the lender has.

7 In co-operation with Marel Food Systems, the authors selected, visited and interviewed four of the largest Vietnamese pangasius processors in order to understand their difficulties and constraints in modernizing their processing lines. The export value of these processors on a yearly basis varied from USD 17 million to USD 61,7 million in 2010 (according to statistics from VASEP sent via email July 22, 2011). These companies are thus an important source of foreign exchange for Vietnam.

8 Vietnam Association of Seafood Exporters and Producers (VASEP) is a non-governmental organization, established on June 12th 1998, based on the principles of volunteer, autonomy and equality. VASEP members include leading Vietnamese seafood producers and exporters and companies providing service to the seafood sector.

9 Iceland has an ECA called TRÚ. This agency has so far been inactive and has never processed a transaction. Since Marel has production facilities in several countries the company can use the services of ECAs in those countries. Iceland, like several smaller states, also has limited membership in international financial institutions (IFIs) and is not a member of the regional development banks (see, for example, Hilmarsson, 2011). This limits access by Icelandic companies to IFI risk mitigation instruments. For more detail about the application of IFI risk mitigation instruments in emerging market economies see, for example, H. P. Hilmarsson (2012).

\section{References}

1. Ascari, R. (2007). Is Export Credit Agency a Misnomer? The ECA Response to a Changing World. - SACE Working Paper 02, February 2007. Internet access: <http://www.sace.it/GruppoSACE/ export/sites/default/download/wpsacen02.pdf>, [accessed October 25, 2012].

2. Asmundson, I., Dorsey, T., Khachatryan, A., Niculcea, I., and Saito, I. (2011). Trade and Trade Finance in the 2008 - 2009 Financial Crisis. - IMF Working Paper, WP/11/16, pp. 1-65. Internet access: <http://www.imf.org/external/pubs/ft/ wp/2011/wp1116.pdf $>$, [accessed September 25, 2012].

3. Chauffour, J., Saborowski, C. (2010). Export Credit Agencies to the Rescue of Trade Finance. Internet access: <http://voxeu.org/index. php?q=node/4515>, [accessed November 25, 2012].

4. EKF (2009a). Case: Olam Buys Danish Equipment with Long-term Loan. Internet access: 
<http://www.ekf.dk/en/WhatWeDo/cases/Pages/ GEA-Process-Engineering.aspx $>$, [accessed June 14, 2013].

5. EKF (2009b). Case: Ukraine Orders Create Jobs in Thisted, Denmark. Internet access: <http:// www.ekf.dk/en/WhatWeDo/cases/Pages/Cimbria.aspx $>$, [accessed November 14, 2013].

6. EKF (2010). Case: EKF Secures Financing of Large FLSmidth Order to Jordan. Internet access: <http://www.ekf.dk/en/WhatWeDo/cases/Pages/ FLSmidth.aspx $>$, [accessed November 14, 2013].

7. EKN (2010). Annual Report. Internet access: <http://www.ekn.se/ar2010/EKNs_annualreport_2010.pdf $>$, [accessed December 12, 2012].

8. Finger, K. M., Schuknecht, L. (1999). Trade, Finance and Financial Crises // The World Trade Organization. Internet access: <http://www.wto. org/english/res_e/booksp_e/special_study_3_e. pdf $>$, [accessed April 12, 2012].

9. Fitzgerald, B., Monson, T. (1989). Preferential Credit and Insurance as Means to Promote Exports // The World Bank Research Observer. No. 4(1), pp. 89-114.

10. Hilmarsson, H. P. (2011). Managing Reform: How can the Baltic States as Aid Donors Best Share their Transition Experience with Less Advanced Economies and what Lessons can they Learn from the International Development Programs of the Nordic Countries? // Review of International Comparative Management. Vol. 12, Iss. 4, October 2011, pp. 682-695. Internet access: <http://www.rmci.ase.ro/no12vol4/06.pdf>, [accessed August 14, 2012].

11. Hilmarsson, H. P. (2012). Small States and Large Private Sector Investments in Emerging Market Economies in Partnership with International Financial Institutions. In Innovation Systems in Small Catching-Up Economies: New Perspectives on Practice and Policy // Springer Book Series on Innovation, Technology and Knowledge Management. Vol. 15, Part 2, pp. 139-158. Internet access: <http://www.springerlink.com/content/ g822445185313n03/>, [accessed September 14, 2012]. DOI: http://dx.doi.org/10.1007/978-14614-1548-0_8.
12. Luo, Y. (2009). Political Risk and Country Risk in International Business. The Oxford Handbook of International Business. - Published by Oxford Handbooks Online: September 2009. DOI: http://dx.doi.org/10.1093/oxfordhb/9780199234 257.001.0001.

13. MIGA (2009). World Investment and Political Risk. Internet access: <http://www.miga.org/documents/flagship09ebook.pdf $>$, [accessed December 12, 2012].

14. MIGA (2010). World Investment and Political Risk. Internet access: <http://www.miga.org/documents/WIPR10ebook.pdf $>$, accessed December $12,2012]$.

15. OECD (2003). Definition of Commercial Risk. Internet access: <http://stats.oecd.org/glossary/ detail.asp?ID=5896>, [accessed June 15, 2013].

16. OECD (n.d). Country Risk Classification. Internet access: <http://www.oecd.org/trade/exportcredits/crc.htm $>$, [accessed July 12, 2013].

17. OECD (n.d.). Export Credits, Official Export Credits Agencies. Internet access: <http://www. oecd.org/about/0,3347,en_2649_34169_1_1_1_1 _1,00.html>, [accessed June 25, 2013].

18. Olam (2011). Annual Report. Available at: $<$ http://olamonline.com/resources\#Annual_ Reports_2011>, [accessed December 1, 2012].

19. Tvardek, S. (2011). Smart Rules for Fair Trade: Export Credit Financing. Trade Finance. Internet access: <http://www.tradefinancemagazine.com/ Article/2954798/Smart-rules-for-fair-tradeExport-Credit-Financing.html>, [accessed September 25, 2012].

20. VASEP (2011). Vietnam Association of Seafood Exporters and Producers. Internet access: <http:// www.vasep.com.vn/>, [accessed June 30, 2013].

21. Yescombe, E. R. (2002) Principles of Project Finance. - Academic Press, London.

22. Yin, R. K. (2009). Case Study Research. Design and Methods (4th ed., Vol. 5). - California: SAGE Inc.

The paper submitted: April 27, 2014 Prepared for publication: June 1, 2014 
Trung Quang DINH, Hilmar bór HILMARSSON

\section{KAIP EKSPORTO KREDITAVIMO AGENTŪROS PADEDA SPRĘSTI BESIVYSTANČIU ŠALIỤ KAPITALUI IMLIUQ PROJEKTỤ FINANSAVIMO PROBLEMAS?}

\section{S a n t r a u k a}

Dauguma besivystančių šalių priskiriamos vidutinių pajamų šalių grupei. Tačiau visos jos ateityje siekia tapti aukštų pajamų šalimis. Didžiausi šių šalių iššūkiai yra eksporto sektoriaus modernizavimas, kuris didina produkcijos pridètinę vertę. Tam, kad modernizuoti eksporto pramonę, vidutinių pajamų šalių įmonès bendradarbiauja su pažangių šalių įmonèmis, pvz., perkant pažangios produkcijos sprendimus. Iš vienos pusès, pažangių šalių ịmonès siekia paspartinti savo gamybos sprendimų eksportą ì besivystančias šalis, kur kapitalo grąža gali būti itin aukšta. Tačiau prekyba su besivystančiomis rinkomis teikia ne tik aukštą pelningumą, bet ir didelę riziką. Kita vertus, besivystančių rinkų įmonès patiria sunkumų, susijusių su modernizavimo kaštais ir ilgo laikotarpio finansavimo problemomis. Todèl šis straipsnis analizuoja kaip Eksporto kredito agentūros (EKA) gali padèti tiek išsivysčiusių, tiek besivystančių šalių ịmonèms.

Straipsnyje teigiama, kad EKA lengvina tarptautinę prekybą ir padeda besivystančių rinkų įmonèms modernizuoti savo gamybą. Tai ypatingai taikytina įmonèms, susiduriančioms su kapitalui imliais projektais, kuriems reikia ilgalaikio finansavimo ar galimybès skolintis svetima valiuta. Toks skolinimasis gali padèti sumažinti realias palūkanų normas ir neįskaičiuoja perteklinès rizikos, su kuria susiduria i̇monès, gaunančios pajamas iš prekybos užsienio valiuta. EKA gali padèti pažangių šalių i̇monèms, isskaitant Europą, valdyti riziką, kuomet yra eksportuojamos pažangios gamybos technologijos i besivystančiose šalyse veikiančias įmones. Šis straipsnis analizuoja EKA vaidmenị paprastinant tarptautinę prekybą su besivystančiomis rinkomis, pateikiant ekonominę tokių i̇monių egzistavimo logiką. Čia taip pat aprašomi EKA siūlomi rizikos mažinimo įrankiai, kurie naudojami praktikoje, pristatant tikrus atvejus, kai įmonès pasinaudojo EKA paslaugomis.

Straipsnyje pateikiama teorinè EKA analizè, išskiriant verslo ir ne verslo rizikas. Taip pat pristatoma EKA reikšmė ekonominių krizių metu bei nurodomas ekonominis jų veiklos pagrindimas. Vèliau pateikiama darbo metodika ir analizuojami EKA riziką mažinantys instrumentai. Galiausiai, išnagrinejus islandiškos įmonès "Marel” veiklą Vietname, pateikiami realūs EKA veiklos atvejai. "Marel” veikla siejama su maisto ruošos įranga, kuri gaminama daugelyje Europos, Amerikos ir Azijos šalių. Šis pavyzdys rodo, kaip vietnamietiškos įmonès gali pasinaudoti EKA paslaugomis produkcijos linijos atnaujinimui ir gamybos pridètinès vertès padidinimui. 